\title{
Solar Based Z Source Inverter for High Power Application
}

\author{
S. Shanmugasundaram \\ Department of Marine Engineering, AMET University, Chennai, India \\ Corresponding author, e-mail: eei@journal.uad.ac.id
}

\begin{abstract}
The different converters are developer in recent years for efficient operation of PV based various controllers for ac load application. The $Z$ source inverter is used as both buck and boost operation. But the proposed paper $Z$ source inverter produce more output voltage than input voltage. In proposed converter produce high power without using the transformer. The space vector modulation is used as to control the speed of an induction motor. The IFOC based SVM produce the pulse and given to the three phase inverter. In induction motor has high power application so the proposed $Z$ source produces high output. The $D C$ link voltage regulation using the filter. The proposed $Z$ source based $P V$ is implemented using MATLAB/SIMULINK environment.
\end{abstract}

Keywords: Photovoltaic (PV), Z Source Inverter (ZSI), Induction Motor (IM), Space Vector Modulation (SVM), Indirect Field Oriented Control (IFOC)

\section{Introduction}

The use of renewable energy such as solar, fuel, battery etc is increasing. The PV has clean, pollution free energy production system. Design numerous PV modules are connected in series to get higher dc link voltage and the inverter converts dc to ac and fed into the induction motor. The more solar cell form PV module. The number of PV module is connected in series and parallel to form a PV array [1-2].

The single diode PV has effective and used as the source of power converter. The output of the photovoltaic depends on the temperature, irradiance and semiconductor material used. The sun radiance fall on the semiconductor material the electron hole pair is created and thus the electricity is produced [3]. The electron hole pair induces the electrons to move and thus the current flows in the circuit. The $Z$ source inverter has less number of switches in the proposed converter. The space vector modulation is used to produce the pulse and fed into the inverter. In induction motor has high power application and the speed of the motor is to control by using the SVM [4].

In industry the high voltage and current based circuit has used. Most of the application the required output as pure sine wave. In order to get the pure sine wave by using the proposed ZSI. The conventional converter has two stage and the proposed ZSI has single stage power conversion from $\mathrm{PV}$ to $\mathrm{AC}$.

\section{Proposed Solution}

The space vector modulation based induction motor is implemented [5].In this paper described that the PV inverter topology it is a high efficiency topology [6]. Firefly algorithm is presented in this paper in this algorithm used to generate the reactive power [7]. The proposed PV based ZSI for induction motor. The proposed circuit configuration is shown in Figure 1. 


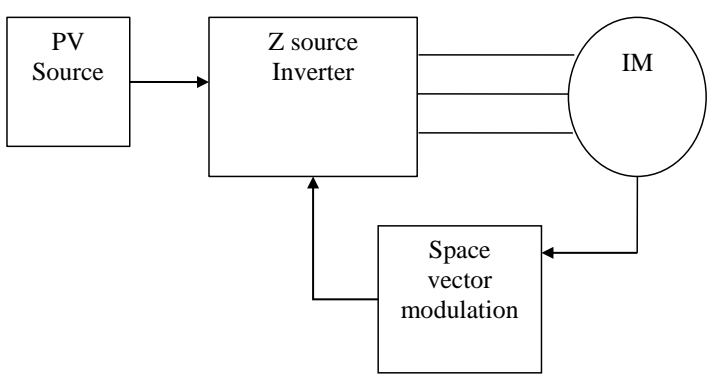

Figure 1. Proposed circuit configuration

\section{a. PV Source}

The Single diode PV model is used in the proposed system. The PV produces the dc power in high voltage and produce distortion less output. The dc linkvoltage will be regulated by using the filter. The equivalent PV circuit is shown in Figure 2.

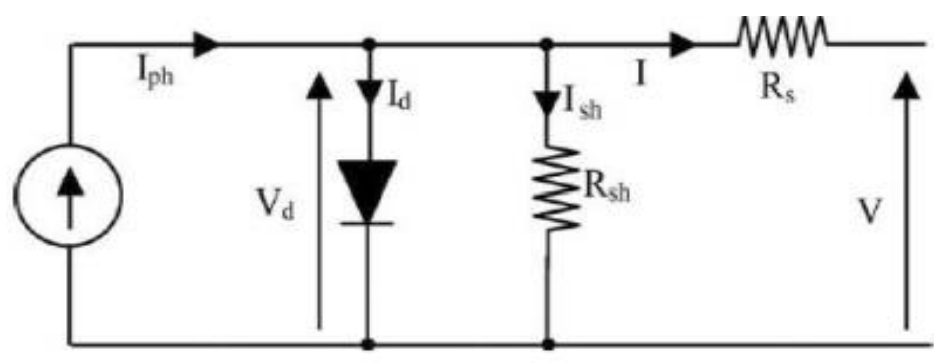

Figure 2. Equivalent PV circuit

In PV the current source indicate the light generate the current.

$$
I_{d}=I s a t\left(-1+e^{\frac{q V_{i n}}{K T_{e m p}}}\right)
$$

where: $I_{\text {sat }}=$ saturation current,

$\mathrm{V}_{\text {in }}=$ applied voltage,

$\mathrm{K}=$ Boltzmann constant,

$\mathrm{T}_{\text {emp }}=$ Temperature

$\mathrm{q}=$ electron charge

b. Z Source Inverter

In Z Source has shoot through and non shoot through state. The proposed ZSI has increase the voltage and it has less voltage across the capacitor. The equivalent circuit diagram of $\mathrm{ZSI}$ is shown in Figure 3. 


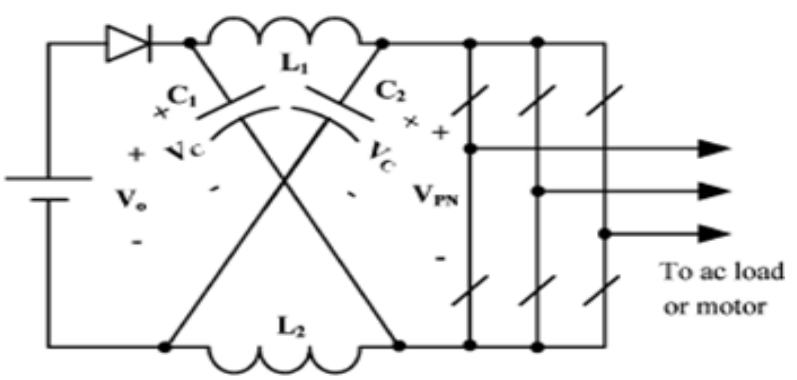

Figure 3. Equivalent circuit diagram of ZSI

Z-source inverter (ZSI) converts the dc into ac wave. The ZSI has enhance the voltage inversion ability and less shoot-through zero states is required to obtained more voltage conversion ratios. ZSI increase the reliability, low voltage waveform distortion. It can be most related to the distributed generation use with low voltage source such as fuel cell, photovoltaic and so on [8].

c. Space vector modulation of induction motor

The space vector modulation improves the performance of the induction motor. The IFOC based SVM is similar as separately excited dc motor. The reference $d$ axis is the adjusted to the rotor flux and rotate the motor in synchronous speed [9-10].

\section{Simulation Results and Discussion}

The proposed PV based ZSI sis shown in Figure 4. The output voltage and current waveform is shown in Figure 5 and 6 . The dc link voltage waveform is shown in Figure 7. The three phase inverter output voltage and current wave is shown in Figure 8. The Speed of an induction motor is shown in Figure 9.

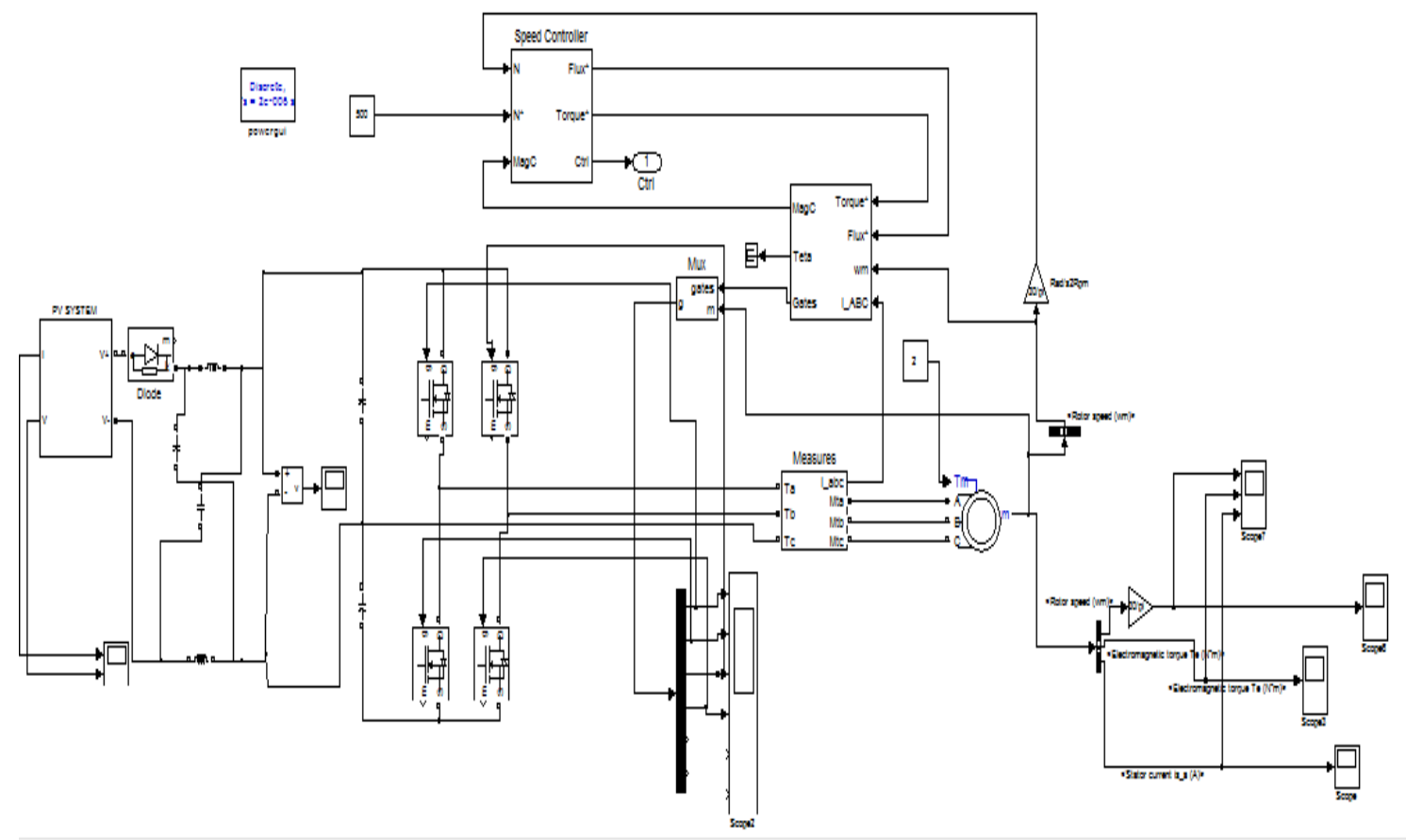

Figure 4. Proposed circuit configurations 


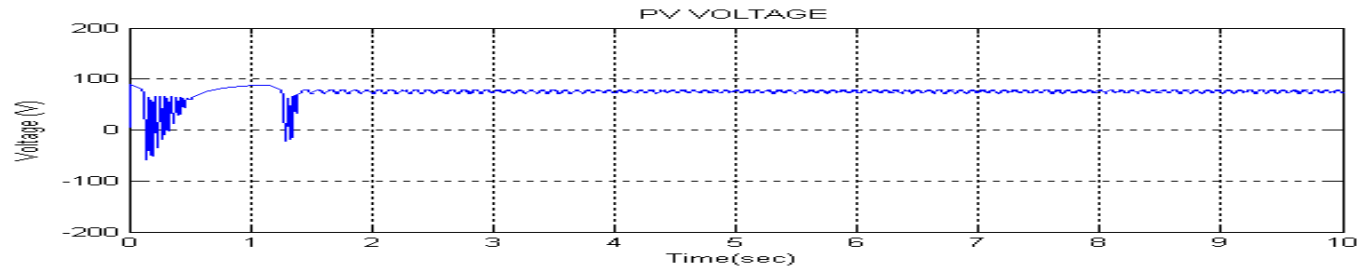

Figure 5. Output voltage waveform of PV

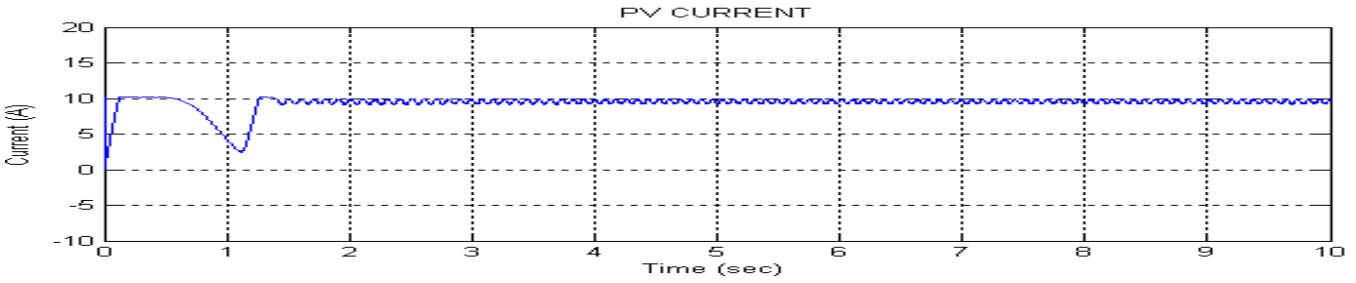

Figure 6. Output current waveform of PV

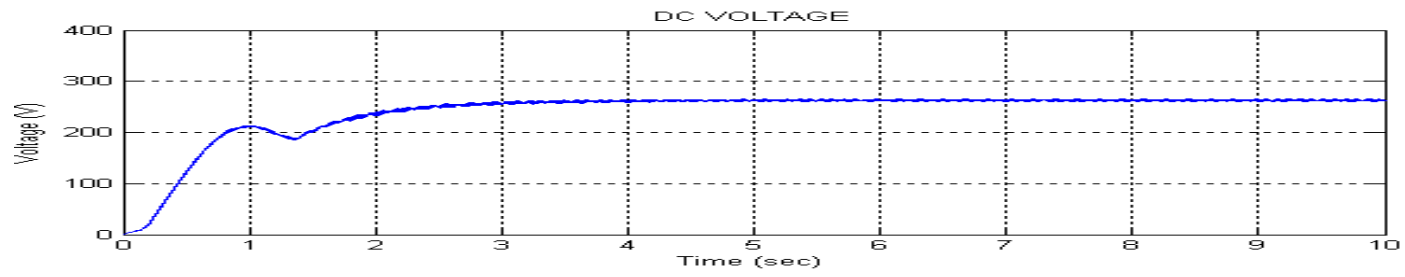

Figure 7. DC link voltage

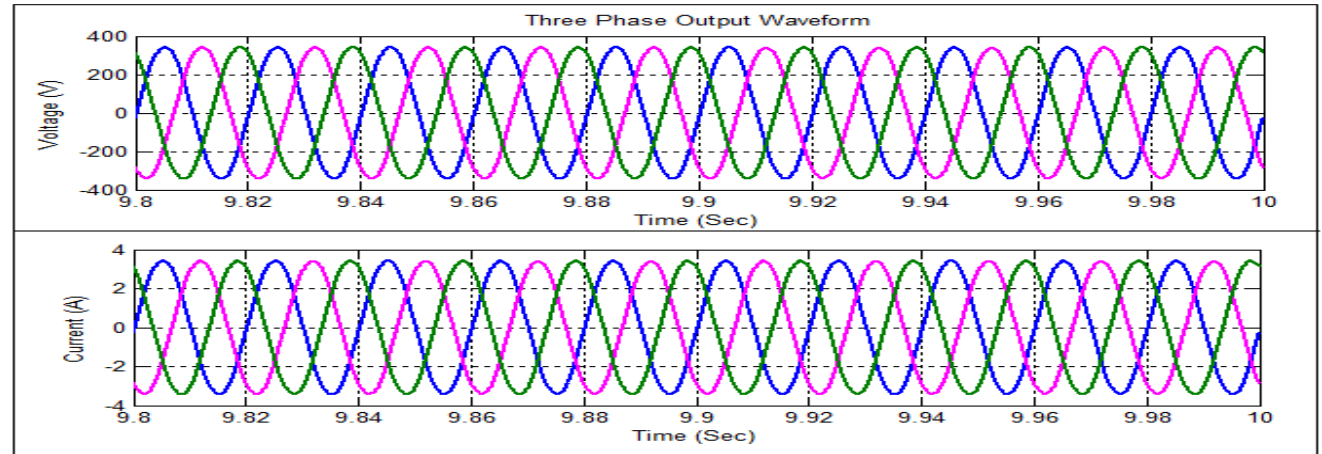

Figure 8. Voltage and current waveform of three phase inverter

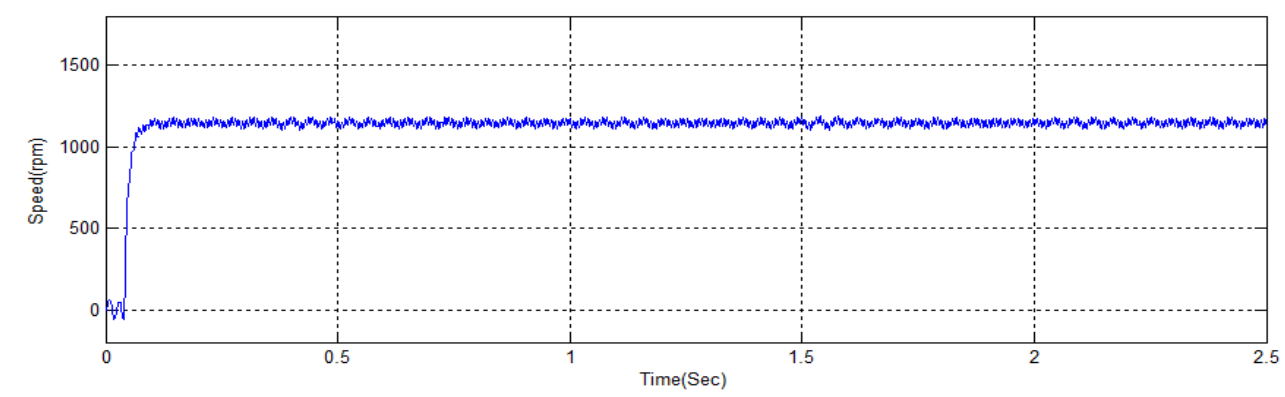

Figure 9. Speed of an induction motor 


\section{Conclusion}

The proposed $Z$ source inverter has increase the voltage and to reduce the distortion in the output of dc link voltage. The speed of an induction motor is regulated by using the IFOC based space vector modulation and the results are verified through the waveform. The ZSI has to convert direct current to alternating current and also increases the output voltage of the proposed inverter.

\section{References}

[1] M Ruiz-Cortés, E Romero-Cadaval, C Roncero-Clemente, E González-Romera, O Husev, Evaluation of Loss in Three-level NPC and T-type Quasi-Z-source Inverters with Modified Carrier Based Modulation Method. 11th IEEE International Conference on Compatibility, Power Electronics and Power Engineering (CPE-POWERENG), Cadiz, Spain. 2017: 638-643.

[2] Pankaj Aswal, Mayank Chaturvedi, Puspender Singh, Pradeep Kumar Juneja. Concentrating Power for MPPT Solar PV Module forming Channelization of Efficient Energy. Indonesian Journal of Electrical Engineering and Computer Science (IJEECS). December 2016. 4(3): 526-531.

[3] B Mandal, T Roy, S Agarwal, PK Sadhu, Switched Capacitor Z-Source Inverter, IEEE 1st International Conference on Power Electronics, Intelligent Control and Energy Systems (ICPEICES), Delhi, 2016: 1-6.

[4] B Mandal, T Roy, S Agarwal, PK Sadhu, Switched Capacitor Z-Source Inverter IEEE 1st International Conference on Power Electronics, Intelligent Control and Energy Systems (ICPEICES), Delhi, 2016; $1-6$.

[5] S Ahmad et al., Hardware Implementation of Grid Connected Transformer-less Semi-Z-source Inverter Topology to Mitigate Common Mode Leakage Current and THD. International Conference on Advances in Electrical Engineering (ICAEE), Dhaka, 2015; 221-225.

[6] Bavitra, K Sinthuja, S Manoharan, N, Rajesh, S. The High Efficiency Renewable PV Inverter Topology. Indian Journal of Science and Technology. 2015; 8(14).

[7] Kannan G, Subramanian DP, Shankar RU. Reactive Power Optimization Using Firefly Algorithm. In Power Electronics and Renewable Energy Systems. 2015: 83-90.

[8] Thumma R, Bhajana VVSK, Kumar Aylapogu P. Design and Simulation of a New ZVT Bi-directional DC-DC Converter for Electric Vehicles. Indonesian Journal of Electrical Engineering and Computer Science (IJEECS). 2017; 7(1): 75-83.

[9] R Padmapriyadharishini, N Kiruthika Indumathi, V Ramakrishnan, Improved Soft Start Capability of Induction Motor Using Solar Power Generation Based Z Source Inverter. IJMSR, 2015; 7(1): 66-76.

[10] Natarajan S, Babu RSR. Reduction of Total Harmonic Distortion in Cascaded H-Bridge Inverter by Pattern Search Technique. International Journal of Electrical and Computer Engineering (IJECE). 2017; 7(6): 3292-3298. 